\title{
Identification of phosphorus use efficiency of different sunflower genotypes at Tandojam-Pakistan
}

Faiza Soomro ${ }^{1}$, Naheed Akhtar Talpur ${ }^{1}$, Mukesh Kumar Soothar ${ }^{*}$, Sobia Baby Jamro ${ }^{1}$, Ayaz Ali Panhwar ${ }^{1}$, Naveed Ali Memon ${ }^{1}$, Jay Kumar Soothar ${ }^{2}$, Umed $\mathrm{Ali}^{3}$ and Muzamil Hussain Soomro ${ }^{4}$

1. Department of Soil Science, Sindh Agriculture University Tandojam-Pakistan

2. Department of Plant Breeding and Genetics, Sindh Agriculture University Tandojam-Pakistan

3. College of Environment and Resources, Huazhong Agricultural University Wuhan-China

4. Department Entomology, Sindh Agriculture University Tandojam-Pakistan

*Corresponding author's email: mukeshksootar@gmail.com

Citation

Faiza Soomro, Naheed Akhtar Talpur, Mukesh Kumar Soothar, Sobia Baby Jamro, Ayaz Ali Panhwar, Naveed Ali Memon, Mahendar Kumar Sootahar, Umed Ali and Muzamil Hussain Soomro. Identification of phosphorus use efficiency of different sunflower genotypes at Tandojam-Pakistan. Pure and Applied Biology. Vol. 7, Issue 3, pp1026-1037. http://dx.doi.org/10.19045/bspab.2018.700122

\begin{tabular}{llll}
\hline \hline Received: 17/04/2018 & Revised: 14/07/2018 & Accepted: 26/07/2018 & Online First: 30/07/2018 \\
\hline \hline
\end{tabular}

\section{Abstract}

A field study, phosphorus use efficiency ratio of eight sunflower genotypes (Samsung 20, Mehran 2, HO-1, Melabour, Samsung 30, Valugur, Chinika and Sputnik) was determined. The control and treatment plots were fertilized with $\mathrm{NP}$ at100-50 kg ha-1 and 100-90 kg ha-1 respectively in randomized completer block design. Results revealed that the overall trend of all genotypes has shown that all agronomic traits and yield parameters were significantly influenced and increased when $\mathrm{P}$ level increased. Treatment and genotypes and the interactive effect of increased $\mathrm{P}$ level and genotype were also significantly affected seed and leaf $\mathrm{P}$-uptakes $(\mathrm{P}<0.05)$. The sunflower crop in treatment and control plots produced plant height 184.39 and $177.69 \mathrm{~cm}$, stem girth 6.45 and $6.22 \mathrm{~cm}$, head diameter 18.85 and $15.72 \mathrm{~cm}$, head weight 1959.8 and 1786.7 $\mathrm{g}$, shoot dry weight 30.13 and $19.11 \mathrm{~g}$, seeds head ${ }^{-1} 2048.8$ and 1588.5 , seed yield $\mathrm{kg} \mathrm{ha}^{-1} 17451$ and $1887.9 \mathrm{~kg} \mathrm{ha}^{-1}$, leaf P-uptake 0.259 and $0.113 \%$, seed P-uptake 0.252 and $0.109 \%$, respectively. The HO-1 surpassed all the sunflower genotypes for agronomic traits with highest values for seeds head ${ }^{-1}$ (2153.5), shoot dry weight $(29.82 \mathrm{~g})$, plant height $(199.97 \mathrm{~cm})$, head diameter $(21.10 \mathrm{~cm})$, head weight head weight $(2279.1 \mathrm{~g})$, stem girth $(7.13 \mathrm{~cm})$ and seed yield (2463 kg ha $\left.{ }^{-1}\right)$. The HO-1 showed higher P-use efficiency ratio than rest of the genotypes. It was observed that sunflower genotypes responded positively to increase rate of $\mathrm{P}$ fertilizer; however, there was significant variation in genotypes for response towards $\mathrm{P}$ use efficiency ratio.

Keywords: P level; P-ratio; P-use efficiency; Sunflower genotypes

\section{Introduction}

Sunflower (Helianthus annuus L.) is one of the four most important oil crops in the world [1, 2]. Because of its moderate cultivation requirements and high oil quality, its acreage has increased in both developed and developing countries [3]. Sunflower oil contains high percentage of 
poly-unsaturated fatty acids that reduces cholesterol in blood and prevents heart diseases [4]. Sunflower oil is quite palatable and contains soluble vitamins A, D, E and K [5-7]. In Pakistan, sunflower has the potential to bridge up the gap between demand and supply of edible oil and it is well adapted to existing agro-ecological conditions. There are many factors which are responsible for low yield; management of fertilizers may be of much importance [8, 9]. The balanced nutrient application for crop production is essential and their imbalance use reduces crop yields. All sources of nutrients may be applied to crops and advocated that foliar fertilization is widely used practice to correct nutritional deficiencies in plants caused by improper supply of nutrients to roots [10]. Phosphorus (P) is an essential nutrient both as a part of several key plant structure compounds and as a catalysis in the conversion of numerous key biochemical reactions in plants [11]. The amounts, forms and associated dynamics of soil $\mathrm{P}$ are influenced by a number of factors including soil type and environmental conditions, as well as landuse and management practices [10]. Phosphorus is involved in controlling key enzyme reactions and in the regulation of metabolic pathways [12]. According to different researchers, almost $90 \%$ of soils in Pakistan are deficient in $\mathrm{P}$ at different severity levels and hence, to apply $\mathrm{P}$ is inevitable [13]. Furthermore, its deficiency trims down the yield from 10 to $15 \%$ [14]. Reliance on the increased use of chemical fertilizers and associated hazards put attention on organic sources which are effective in promoting health and productivity of the soil. Integrated management of chemical fertilizers and organic wastes may be an important strategy for sustainable production of crops [15]. Sunflower in terms of $\mathrm{P}$ use efficiency in nutrient solution and the growth of both species responded strongly to increasing $\mathrm{P}$ supply. Sunflower is more efficient in terms of $\mathrm{P}$ uptake and utilization at optimal and sub-optimal $\mathrm{P}$ levels as compared to other oil seed crops. Pakistani soils are calcareous, generally deficient in $\mathrm{P}$ and its deficiency can reduce the yield of crops upto 15 percent [16, 17]. Kumar et al. [18] conducted an experiment and declared that in various $\mathrm{P}$ doses, 60 and $90 \mathrm{~kg} \mathrm{P} \mathrm{ha}^{-1}$ emerged to be the ideal as for the vegetative growth of plants. In other study [19] conveyed that growth and yield are significantly affected by $\mathrm{P}$ rate. There are different views of scientists about role of phosphorus on oil percentage of crops. Lickfett et al. [20] revealed that plant height was enhanced by phosphorus fertilizer. The present study was undertaken on the identification of $\mathrm{P}$ use efficiency of different sunflower genotypes.

\section{Materials and methods}

The present study was conducted on the identification of phosphorus use efficiency of sunflower genotypes at the experimental fields of oil seeds section, Agriculture Research Institute Tandojam Pakistan during 2016.

The experimental land was prepared in offseason and soaked. After soaking dose when land came in condition, the seedbed was prepared as per recommendations. Having a good seed bed, the main plot was divided into three main plots in the RCBD and of these three plots each was divided into eight sub-units of $3.0 \mathrm{~m} \times 5.0 \mathrm{~m}\left(15.0 \mathrm{~m}^{2}\right)$. In all, 24 sub-plots were prepared in three replicates of eight treatments. The seeds of eight sunflower genotypes i.e. Mehran 2, Valugur, Samsung 20, Samsung 30, Chinika, Sputnik, HO-1 and Melabour were sown by drilling, after emergence of seedling, thinning was performed to maintain the recommended plant population with $45 \mathrm{~cm}$ plant to plant and $60 \mathrm{~cm}$ row to row spacing. 


\section{Soil analysis}

Soil samples were collected at two depths i.e. $0-15 \mathrm{~cm}$ and $15-30 \mathrm{~cm}$ and these samples were brought to the laboratory of Plant Nutrition, Department of Soil Science, Faculty of Crop Production, Sindh Agriculture University, Tandojam for some basic physico-chemical properties Texture, electrical conductivity, $\mathrm{pH}$, organic matter \% and AB-DTPA extractable P.

\section{Leaf/Seed $P$}

The sunflower leaves and seeds were taken from experimental field for the determination of leaf/seed $\mathrm{P}$ content from both sunflower genotypes treatments. Diagnostic leaf and sunflower seed samples were digested with nitric and perchloric acid mixture (1:2). The samples were analysed for $\mathrm{P}$ content by developing vanadomolybdo phosphoric acid yellow colour method.

\section{P-Use efficiency Ratio}

The P- use efficiency ratio was calculated according to the formula suggested by Brar et al. [21].

\section{Agronomic observations}

Plant height $(\mathrm{cm})$, Stem girth $(\mathrm{cm})$, Head diameter $(\mathrm{cm})$, Head weight $(\mathrm{g})$, Shoot dry weight $(\mathrm{g})$, Seeds head ${ }^{-1}$, Seed yield $\left(\mathrm{kg} \mathrm{ha}^{-1}\right)$

\section{Statistical analysis}

The data thus collected were statistically analysed using Students Statistical Software Package (Statistix ver. 8.1). The ANOVA was derived to examine the significance of treatment effect; while the LSD test was applied to compare the mean values for assessing significance of effect among treatments.

\section{Results}

Eight different sunflower genotypes; Samsung 20, Mehran 2, HO-1, Melabour, Samsung 30, Valugur, Chinika and Sputnik were identified for $\mathrm{P}$ use efficiency, agronomical parameters and yield of the sunflower.

\section{Soil physic-chemical properties}

The data related to physic-chemical properties of soil used in this experiment. The soil was clay loam in texture, slightly alkaline, non-saline in nature, low in organic matter and available $\mathrm{P}$ at both soil depths i.e. 0-15 and $15-30 \mathrm{~cm}$.

\section{Plant height (cm)}

The results (Table 1) showed that increased $P$ level had significant impact among sunflower genotypes, which showed significant variation $(\mathrm{P}<0.05)$ in their plant height. The interactive effect of treatments and genotypes was also found significant $(\mathrm{P}<0.05)$. The increased rate of $\mathrm{P} 90 \mathrm{~kg} \mathrm{ha}^{-1}$ increased sunflowers plant height $184.39 \mathrm{~cm}$ as compared to those in control plots with recommended $\mathrm{P}$ level of $50 \mathrm{~kg} \mathrm{ha}^{-1}$ (177.69 $\mathrm{cm})$. The increase in plant height in plots given $\mathrm{P}$ at increased rates was $3.77 \%$ over control. The varietal response showed that sunflower variety HO-1 produced maximum plants height $(199.97 \mathrm{~cm})$, followed by Mehran 2, Chinika and Sputnik with average plant height of 190.09, 186.44 and 182.76 $\mathrm{cm}$ respectively. However, the minimum plant height $(169.01 \mathrm{~cm})$ was recorded in genotype Valugur. Sunflower genotypes Melabour and Samsung 20 showed similarity in plant height; while Samsung 30, Valugur and Sputnik also showed more or less $(\mathrm{P}>0.05)$ plant height. The interactive effect showed that the maximum plant height 213.61 was found in variety HO-1 when treated with increased P level $(90 \mathrm{~kg})$; while genotype Samsung 30 in control showed lowest plant height $(168.67 \mathrm{~cm})$.

\section{Stem girth $(\mathbf{c m})$}

The effect of P level was significant on the stem girth of sunflower $(\mathrm{P}<0.05)$ and presented in (Table 1). It showed variation $(\mathrm{P}<0.05)$ due to different genotypes as well as interactive effect of $\mathrm{P}$ treatments and genotypes. The increased P level $\left(90 \mathrm{~kg} \mathrm{ha}^{-}\right.$ $\left.{ }^{1}\right)$ produced sunflower plants with thicker stems $(6.45 \mathrm{~cm})$ as compared to those in 
control plots with recommended $\mathrm{P}$ level of $50 \mathrm{~kg} \mathrm{ha}^{-1}(6.22 \mathrm{~cm})$. The increased $\mathrm{P}$ rate also enhanced stem girth (3.70\%) over control. Among the genotypes, The $\mathrm{HO}^{-1}$ possessed maximum stem girth $7.13 \mathrm{~cm}$, followed by Mehran 2, Sputnik and Chinika with average stem girth of 7.10, 6.67 and $6.26 \mathrm{~cm}$, respectively. However, the minimum stem girth $5.98 \mathrm{~cm}$ was measured in genotype Valugur. Rest of the genotypes Samsung 20, Melabour and Valugur were more or less equal in stem girth $(\mathrm{P}>0.05)$.

Table 1. Effect of $P$ level on the growth and yield parameters of sunflower genotypes

\begin{tabular}{|c|c|c|c|c|}
\hline \multicolumn{5}{|c|}{$\begin{array}{l}\text { Plant height }(\mathrm{cm}) \\
\end{array}$} \\
\hline S. No. & Genotypes & Control (NP@100-50 kg ha') & Treatment(NP @100-90 kg ha') & Mean for genotypes \\
\hline 1 & Samsung 20 & 185.00 & 175.07 & $180.03 \mathrm{C}$ \\
\hline 2 & Mehran 2 & 177.33 & 202.85 & $190.09^{\mathrm{B}}$ \\
\hline 3 & $\mathrm{HO}-1$ & 186.33 & 213.61 & $199.97^{\mathrm{A}}$ \\
\hline 4 & Melabour & 173.00 & 168.40 & $170.70^{\mathrm{C}}$ \\
\hline 5 & Samsung 30 & 168.67 & 169.95 & $169.31^{\mathrm{D}}$ \\
\hline 6 & Valugur & 170.84 & 167.18 & $169.01^{D}$ \\
\hline 7 & Chinika & 185.31 & 187.57 & $186.44^{\mathrm{BC}}$ \\
\hline 8 & Sputnik & 175.00 & 190.51 & $182.76^{\mathrm{D}}$ \\
\hline \multicolumn{2}{|c|}{ Mean for reatments } & $177.69^{\mathrm{B}}$ & $184.39^{\mathrm{A}}(3.77 \%)$ & - \\
\hline \multicolumn{5}{|c|}{ Stem girth $(\mathrm{cm})$} \\
\hline 1 & Samsung 20 & 5.89 & 6.12 & $6.01^{\mathrm{E}}$ \\
\hline 2 & Mehran 2 & 6.45 & 7.10 & $6.77^{\mathrm{B}}$ \\
\hline 3 & $\mathrm{HO}-1$ & 6.79 & 7.47 & $7.13^{\mathrm{A}}$ \\
\hline 4 & Melabour & 6.14 & 5.89 & $6.01^{\mathrm{E}}$ \\
\hline 5 & Samsung 30 & 6.22 & 5.95 & $\mathbf{6 . 0 8}^{\mathrm{DE}}$ \\
\hline 6 & Valugur & 6.12 & 5.85 & $5.98^{\mathrm{E}}$ \\
\hline 7 & Chinika & 5.97 & 6.56 & $6.26^{\mathrm{CD}}$ \\
\hline 8 & Sputnik & 6.19 & 6.67 & $6.43^{\mathrm{C}}$ \\
\hline \multicolumn{2}{|c|}{ Mean for treatments } & $6.22^{\mathrm{B}}$ & $6.45 \mathrm{~A}(3.70 \%)$ & - \\
\hline \multicolumn{5}{|c|}{ Head diameter $(\mathbf{c m})$} \\
\hline 1 & Samsung 20 & 14.20 & 17.10 & $15.65^{\mathrm{D}}$ \\
\hline 2 & Mehran 2 & 17.29 & 20.82 & $19.06^{\mathrm{B}}$ \\
\hline 3 & HO-1 & 19.14 & 23.06 & $21.10^{A}$ \\
\hline 4 & Melabour & 14.15 & 17.05 & $15.60^{\mathrm{D}}$ \\
\hline 5 & Samsung 30 & 14.36 & 17.29 & $15.82^{\mathrm{D}}$ \\
\hline 6 & Valugur & 14.23 & 17.14 & $15.69^{\mathrm{D}}$ \\
\hline 7 & Chinika & 15.87 & 19.12 & $17.49^{\mathrm{C}}$ \\
\hline 8 & Sputnik & 16.55 & 19.15 & $17.85^{\mathrm{C}}$ \\
\hline \multicolumn{2}{|c|}{ Mean for treatments } & $15.72^{\mathrm{B}}$ & $18.84^{\mathrm{A}}(19.85 \%)$ & - \\
\hline \multicolumn{5}{|c|}{ Head weight $(\mathrm{g})$} \\
\hline 1 & Samsung 20 & 1698.5 & 1778.5 & $1738.5^{\mathrm{D}}$ \\
\hline 2 & Mehran 2 & 1951.4 & 2166.0 & $2058.7^{\mathrm{B}}$ \\
\hline 3 & HO-1 & 2160.1 & 2398.1 & $2279.1^{A}$ \\
\hline 4 & Melabour & 1597.4 & 1773.2 & $1685.3^{\mathrm{D}}$ \\
\hline 5 & Samsung 30 & 1620.4 & 1798.6 & $1709.5^{\mathrm{D}}$ \\
\hline 6 & Valugur & 1606.5 & 1783.2 & $1694.8^{\mathrm{D}}$ \\
\hline 7 & Chinika & 1791.5 & 1988.6 & $1890.1^{\mathrm{C}}$ \\
\hline 8 & Sputnik & 1867.5 & 1992.0 & $1929.7^{\mathrm{C}}$ \\
\hline \multicolumn{2}{|c|}{ Mean for treatments } & $1786.7^{\mathrm{B}}$ & $1959.8^{\mathrm{A}}(9.69 \%)$ & - \\
\hline
\end{tabular}




\section{Head diameter $(\mathrm{cm})$}

The data regarding head diameter of sunflower genotypes is presented in (Table 1). Head diameter was significantly affected by increase $\mathrm{P}$ level $(\mathrm{P}<0.05)$ as compared to control was observed significant.

Among the genotypes, significant variation was observed in head diameter $(\mathrm{P}>0.05)$. The interactive impact of treatments and genotypes on head diameter was not significant $(\mathrm{P}<0.05)$..

The $\mathrm{P}$ application level $90 \mathrm{~kg} \mathrm{ha}^{-1}$ produced maximum number of sunflower head diameter $(18.85 \mathrm{~cm})$ as compared to control plots with recommended $P$ level of $50 \mathrm{~kg}$ ha 1 (15.72 cm). Among different sunflower genotypes, the HO-1 genotype produced maximum head diameter. The HO-1 produced maximum head diameter (21.10 $\mathrm{cm}$ ), followed by Mehran 2, Sputnik and Chinika with average head diameter of $19.06,17.85$ and $17.49 \mathrm{~cm}$, respectively. However, the minimum head diameter $(15.60 \mathrm{~cm})$ was recorded in genotypes Melabour. The interactive effect indicated that the maximum head diameter $(23.06 \mathrm{~cm})$ was recorded in variety $\mathrm{HO}-1$ when treated with increased $\mathrm{P}$ level $(90 \mathrm{~kg})$; while genotype Melabour in control remained lowest in head diameter $(14.15 \mathrm{~cm})$. The increase in head diameter in plots given $\mathrm{P}$ at increased rates was 19.85 percent over control.

\section{Head weight (g)}

The data regarding the effect of phosphorus use efficiency of sunflower genotypes on head weight is summarized in Table 1.

The head weight of sunflower genotypes significantly increased with the increased $\mathrm{P}$ level $(\mathrm{P}<0.05)$. It also showed variation in head weight $(\mathrm{P}>0.05)$ whereas the interactive effect of treatments and genotypes was insignificant on head weight. In between, increased $\mathrm{P}$ level and control $\mathrm{P}$ level, the increased $\mathrm{P}$ level $\left(90 \mathrm{~kg} \mathrm{ha}^{-1}\right)$ produced heavier sunflower heads $1959.5 \mathrm{~g}$ as compared to control plots with recommended $\mathrm{P}$ level of $50 \mathrm{~kg} \mathrm{ha}^{-1} 1786.7 \mathrm{~g}$. The increase in head weight in plots given $\mathrm{P}$ at higher rates was 9.69 percent over control. The HO-1 produced heavier heads (2279.1 g) followed by genotypes Mehran 2, Sputnik and Chinika with average head weight of 2058.7, 1929.7 and $1890.1 \mathrm{~g}$, respectively. However, the lowest head weight (1685.3 g) was observed in genotype Melabour. The genotypes, Samsung 20, Melabour, Samsung 30 and Valugur showed insignificant variation in head weight $(\mathrm{P}>0.05)$; while Sputnik and Chinika also showed similarity $(\mathrm{P}>0.05)$ for this trait. The interactive effect indicated that the maximum head weight $2398.1 \mathrm{~g}$ was recorded in variety HO-1 when treated with increased P level; while genotypes Melabour remained lowest in head weight (1597.4 g) when sown in control.

\section{Shoot dry weight (g)}

The results regarding shoot dry weight is given in (Table 2) and showed that the effect of applied $\mathrm{P}$ on shoot dry weight was significant $(\mathrm{P}<0.05)$ and eight genotypes variation were also significant $(\mathrm{P}<0.05)$. However, interactive effect of treatments and genotypes was insignificant on shoot dry weight $(\mathrm{P}>0.05)$. The increased rate of $\mathrm{P}$ $\left(90 \mathrm{~kg} \mathrm{ha}^{-1}\right.$ ) resulted in higher shoot dry weight $(30.13 \mathrm{~g})$ as compared to control. The results showed that the shoot dry weight under lower $\mathrm{P}$ application rate of $50 \mathrm{~kg} \mathrm{ha}^{-1}$ (Control), were declined (19.11 g). The increase in shoot dry weight in treatment plots was 57.67 percent over control. The varietal response showed that $\mathrm{HO}-1$ produced maximum shoot dry weight (29.82 g), followed by genotypes Mehran 2, Sputnik and Chinika with average shoot dry weight of 27.29, 26.01 and $24.37 \mathrm{~g}$, respectively. However, the lowest shoot dry weight $(22.19 \mathrm{~g})$ was recorded in genotype Melabour. Sunflower genotypes Melabour and Valugur as well as Samsung 20 and 
Samsung 30 showed similarity $(\mathrm{P}>0.05)$ for shoot dry weight. The interactive effect showed that the highest shoot dry weight $(36.44 \mathrm{~g})$ was noted in variety $\mathrm{HO}-1$ when treated with increased $\mathrm{P}$ level $(90 \mathrm{~kg})$; while genotype Melabour remained least for shoot dry weight (17.15 g).

\section{Seed head-1}

The results about seed head ${ }^{-1}$ have been summarized in (Table 2). The data showed that the significant variation in the number of seeds head ${ }^{-1}$ due to treatment effect and for genotypes of diversified origin $(\mathrm{P}<0.05)$; while insignificant interactive effect of treatment and genotype $(\mathrm{P}>0.05)$. The treatment comprised of increased rate of $\mathrm{P}$ (NP @100-90 kg ha-1) resulted in an increased number of seeds $\left(2048.8\right.$ head $\left.^{-1}\right)$ over control (NP @ 100-50 kg ha ${ }^{-1}$ ) where the number of seeds declined to 1588.5 head $^{-1}$. The increase in seeds head ${ }^{-1}$ in treatment plots was 28.98 percent over control. The varietal response showed that HO-1 produced maximum number of seeds (2153.5 head $\left.^{-1}\right)$, followed by genotypes Mehran 2, Sputnik and Chinika with 2000.2, 1911.0 and 1827.2 seeds head $^{-1}$, respectively. However, the lowest number of seeds (1647.7 head $\left.^{-1}\right)$ was recorded in genotype Valugur. Sunflower genotypes Samsung 20, Melabour, Samsung 30 and Valugur showed similarity $(\mathrm{P}>0.05)$ in number of seeds head ${ }^{-1}$. The interactive effect showed that the highest number of seeds $\left(2373.4\right.$ head $\left.^{-1}\right)$ was recorded in variety $\mathrm{HO}-1$ when treated with increased $\mathrm{P}$ level (90 kg); while genotype Melabour in control remained least for number of seeds $\left(1429.8\right.$ head $\left.^{-1}\right)$.

\section{Seed yield (kg ha-1)}

The results showed in this (Table 2) related to the data on sunflower seed yield $\mathrm{kg} \mathrm{ha}^{-1}$ that increased $\mathrm{P}$ level resulted in a significant effect on seed yield $\mathrm{kg} \mathrm{ha} \mathrm{ha}^{-1}$ $(\mathrm{P}<0.05)$; and the seed yield $\mathrm{kg} \mathrm{ha}^{-1}$ varied significantly in sunflower genotypes used in this study $(\mathrm{P}<0.05)$; whereas the interactive effect of treatments and genotypes was insignificant $(\mathrm{P}>0.05)$ on seed yield $\mathrm{kg}$ ha ${ }^{1}$.It is suggested that increased $\mathrm{P}$ level. Produced higher sunflower yields $(17451 \mathrm{~kg}$ $\left.\mathrm{ha}^{-1}\right)$ as compared to those in control plots with recommended $\mathrm{P}$ level of $50 \mathrm{~kg} \mathrm{ha}^{-1}$ $\left(1887.9 \mathrm{~kg} \mathrm{ha}^{-1}\right)$. The treatment plots increased 15.55 percent seed yield $\mathrm{kg} \mathrm{ha}^{-1}$ over control plots. In variety, $\mathrm{HO}-1$ produced higher seed yields $\left(2463 \mathrm{~kg} \mathrm{ha}^{-1}\right)$, followed by genotypes Sputnik, Mehran 2, and Chinika with average seed yield of 2179, 2153 and $2053 \mathrm{~kg} \mathrm{ha}^{-1}$, respectively. However, the lowest seed yield (1846 kg ha $\left.{ }^{1}\right)$ was recorded in genotype Melabour. The genotypes Samsung 20, Melabour, Samsung 30 and Valugur showed similarity for seed yield $\mathrm{kg} \mathrm{ha}^{-1}(\mathrm{P}>0.05)$; and Mehran 2, Sputnik and Chinika also showed negligible difference in seed yield $(\mathrm{P}>0.05)$. The treatment interaction showed that the maximum seed yield (2463 $\left.\mathrm{kg} \mathrm{ha}^{-1}\right)$ was recorded in variety $\mathrm{HO}-1$, when it was treated with increased $\mathrm{P}$ level; while genotype Melabour remained lowest in seed yield (1846 kg ha- $\left.{ }^{1}\right)$ when sown in control plot.

\section{Leaf P-uptake (\%)}

The results showed in this (Table 2) for the data on leaf P-uptake described that the effect of higher rate of $\mathrm{P}$ application, genotypes as well as treatment and genotype interaction was significant on leaf P-uptake $(\mathrm{P}<0.05)$.the further results showed that the increased rate of $\mathrm{P}\left(90 \mathrm{~kg} \mathrm{ha}^{-1}\right)$ resulted in higher leaf P-uptake (0.259 \%) as compared to control $0.113 \%$ leaf P-uptake recorded in crop given lower P. A high significant difference has been recorded for in treatment plots where 129.20 percent leaf $\mathrm{P}$ uptake was higher over control. The varietal effect showed that the leaf P-uptake was higher in genotype Sputnik $0.335 \%$, followed by genotypes Chinika, Valugur and HO-1 with average leaf P-uptake of $0.267,0.224$ and 
0.188 percent, respectively. However, the lowest leaf P-uptake (0.093 \%) was determined in genotype Samsung 20. The treatment and genotype interaction showed that the highest leaf P-uptake $(0.564 \%)$ was examined in genotype Sputnik when treated with increased P level $\left(90 \mathrm{~kg} \mathrm{ha}^{-1}\right)$; while the minimum leaf P-uptake $(0.076 \%)$ was determined in genotype Samsung 20 in control.

Table 2. Effect of $P$ level on the growth and yield parameters of sunflower genotypes

\begin{tabular}{|c|c|c|c|c|}
\hline \multicolumn{5}{|c|}{ Shoot dry weight $(\mathrm{g})$} \\
\hline S. No. & Genotypes & Control(NP@100-50 kg ha') & Treatment(NP @100-90 kg ha-1) & Mean for genotypes \\
\hline 1 & Samsung 20 & 17.64 & 27.31 & $22.47^{\mathrm{DE}}$ \\
\hline 2 & Mehran 2 & 20.95 & 33.62 & $27.29^{\mathrm{B}}$ \\
\hline 3 & HO-1 & 23.20 & 36.44 & $29.82^{\mathrm{A}}$ \\
\hline 4 & Melabour & 17.15 & 27.22 & 22.19E \\
\hline 5 & Samsung 30 & 17.40 & 27.61 & $22.51^{\mathrm{DE}}$ \\
\hline 6 & Valugur & 17.25 & 27.37 & $22.31^{\mathrm{E}}$ \\
\hline 7 & Chinika & 18.84 & 29.89 & $24.37^{\mathrm{CD}}$ \\
\hline 8 & Sputnik & 20.46 & 31.56 & $26.01^{\mathrm{BC}}$ \\
\hline \multicolumn{2}{|c|}{ Mean for treatments } & $\mathbf{1 9 . 1 1}^{\mathrm{B}}$ & $\mathbf{3 0 . 1 3}^{\mathrm{A}}(\mathbf{5 7 . 5 6 \%})$ & - \\
\hline \multicolumn{5}{|c|}{ Seeds head $^{-1}$} \\
\hline 1 & Samsung 20 & 1434.3 & 1945.2 & $1689.7^{\mathrm{D}}$ \\
\hline 2 & Mehran 2 & 1746.4 & 2253.9 & $2000.2^{\mathrm{B}}$ \\
\hline 3 & HO-1 & 1933.5 & 2373.4 & $2153.5^{\mathrm{A}}$ \\
\hline 4 & Melabour & 1429.8 & 1871.1 & $1650.5^{\mathrm{D}}$ \\
\hline 5 & Samsung 30 & 1450.4 & 1888.3 & $1669.3^{\mathrm{D}}$ \\
\hline 6 & Valugur & 1437.9 & 1857.5 & $1647.7^{\mathrm{D}}$ \\
\hline 7 & Chinika & 1570.3 & 2084.1 & $1827.2^{\mathrm{C}}$ \\
\hline 8 & Sputnik & 1705.1 & 2116.8 & 1911.0 ${ }^{\mathrm{BC}}$ \\
\hline Mean & r treatments & $1588.5^{\mathrm{B}}$ & $2048.8^{A}(28.98 \%)$ & - \\
\hline \multicolumn{5}{|c|}{ Seed yield $\left(\mathrm{kg} \mathrm{ha}^{-1}\right)$} \\
\hline 1 & Samsung 20 & 1720 & 1986 & $1853^{\mathrm{C}}$ \\
\hline 2 & Mehran 2 & 2026 & 2280 & $2153^{B}$ \\
\hline 3 & HO-1 & 2246 & 2680 & $2463^{A}$ \\
\hline 4 & Melabour & 1713 & 1980 & $1846^{\mathrm{C}}$ \\
\hline 5 & Samsung 30 & 1740 & 2006 & $1873^{\mathrm{C}}$ \\
\hline 6 & Valugur & 1726 & 1986 & $1856^{\mathrm{C}}$ \\
\hline 7 & Chinika & 1886 & 2220 & $2053^{B}$ \\
\hline 8 & Sputnik & 2046 & 2313 & $2179^{B}$ \\
\hline Mean & r treatments & $1887.9^{B}$ & $17451^{\mathrm{A}}(15.55 \%)$ & $\cdot$ \\
\hline \multicolumn{5}{|c|}{ Leaf P-uptake (\%) } \\
\hline 1 & Samsung 20 & 0.109 & 0.139 & $0.124^{\mathrm{e}}$ \\
\hline 2 & Mehran 2 & 0.164 & 0.370 & $0.267^{\mathrm{b}}$ \\
\hline 3 & $\mathrm{HO}-1$ & 0.106 & 0.564 & $0.335^{\mathrm{a}}$ \\
\hline 4 & Melabour & 0.076 & 0.109 & $0.093^{\mathrm{f}}$ \\
\hline 5 & Samsung 30 & 0.100 & 0.155 & $0.128^{\mathrm{e}}$ \\
\hline 6 & Valugur & 0.118 & 0.139 & $0.129^{\mathrm{e}}$ \\
\hline 7 & Chinika & 0.109 & 0.267 & $0.188^{\mathrm{d}}$ \\
\hline 8 & Sputnik & 0.118 & 0.330 & $0.224^{\mathrm{c}}$ \\
\hline \multicolumn{2}{|c|}{ Mean for treatments } & 0.113 & $0.259(129.20 \%)$ & - \\
\hline
\end{tabular}

\section{Seed P-uptake (\%)}

The results in (Table 3) showed that the analysis of variance for the data on seed P- uptake indicated that the effect of increased $P$ rate, genotypes as well as interactive effect of treatments and genotypes was significant 
on seed P-uptake $(\mathrm{P}<0.05)$. The data indicated that the increased rate of $\mathrm{P}(90 \mathrm{~kg}$ $\left.\mathrm{ha}^{-1}\right)$ resulted in higher seed P-uptake $(0.252$ $\%$ ) as compared to $0.109 \%$ (control) seed Puptake recorded in crop given lower $\mathrm{P}$ (50 $\mathrm{kg} \mathrm{ha}^{-1}$. The seed P-uptake in treatment plots was 131.19 percent higher over control. The varietal effect showed that the seed P-uptake was higher in genotype Chinika $(0.337 \%)$, followed by genotypes Sputnik, Melbour and Samsung 30 with average seed P-uptake of $0.323,0.308$ and 0.292 percent, respectively. However, the lowest seed Puptake $(0.181 \%)$ was determined in genotype Samsung 20. The treatment and genotype interaction showed that the highest seed P-uptake $(0.409 \%)$ was determined in genotype Chinika when treated with increased $\mathrm{P}$ level $\left(90 \mathrm{~kg} \mathrm{ha}^{-1}\right)$; while the minimum seed P-uptake $(0.109 \%)$ was recorded in genotype Samsung 20 in control.

\section{P-Use efficiency Ratio}

The results regarding P-use efficiency ratio has been summarized in (Table 3) and showed that the effect of increased phosphorus level on different sunflower genotypes.a significant impact on P-use efficiency ratio of different sunflower genotypes with increasing $\mathrm{P}$ application rates have been observed. The highest P-use efficiency ratio 482 was recorded in variety HO-1, followed by Chinika, Sputnik, Melabour and Samsung-30 with P-use efficiency ratio of 371, 296, 296, and 295, respectively. However, the lowest $\mathrm{P}$ use efficiency ratio (282) was determined in genotype Mehran 2. The trend has indicated that sunflower genotypes responded positively to increased rate of $\mathrm{P}$ fertilizer; however, there was significant $(\mathrm{P}<0.05)$ variation in genotypes for response towards $P$ use efficiency ratio.

Table 3. Effect of $\mathbf{P}$ level on the growth and yield parameters of sunflower genotypes

\begin{tabular}{|c|c|c|c|c|}
\hline \multicolumn{5}{|c|}{ Seed P-uptake (\%) } \\
\hline S. No. & Genotypes & Control(NP @100-50 kg ha-1) & Treatment(NP @100-90 kg ha-1) & Mean for genotypes \\
\hline 1 & Samsung 20 & 0.109 & 0.252 & $0.181^{\mathrm{h}}$ \\
\hline 2 & Mehran 2 & 0.276 & 0.370 & $0.323^{\mathrm{b}}$ \\
\hline 3 & HO-1 & 0.264 & 0.409 & $0.337^{\mathrm{a}}$ \\
\hline 4 & Melabour & 0.215 & 0.246 & $0.231^{\mathrm{g}}$ \\
\hline 5 & Samsung 30 & 0.212 & 0.333 & $0.273^{\mathrm{e}}$ \\
\hline 6 & Valugur & 0.248 & 0.294 & $0.271^{\mathrm{f}}$ \\
\hline 7 & Chinika & 0.248 & 0.336 & $0.292^{\mathrm{d}}$ \\
\hline 8 & Sputnik & 0.252 & 0.364 & $0.308^{c}$ \\
\hline \multicolumn{2}{|c|}{ Mean for treatments } & 0.109 & $0.252(131.19 \%)$ & - \\
\hline \multicolumn{5}{|c|}{ P-Use efficiency Ratio } \\
\hline 1 & Samsung 20 & 1720 & 1986 & 295 \\
\hline 2 & Mehran 2 & 2026 & 2280 & 282 \\
\hline 3 & HO-1 & 2246 & 2680 & 482 \\
\hline 4 & Melabour & 1713 & 1980 & 296 \\
\hline 5 & Samsung 30 & 1740 & 2006 & 295 \\
\hline 6 & Valugur & 1726 & 1986 & 288 \\
\hline 7 & Chinika & 1886 & 2220 & 371 \\
\hline 8 & Sputnik & 2046 & 2313 & 296 \\
\hline \multicolumn{2}{|c|}{ Mean for treatments } & $1887.9^{B}$ & $1745.1^{A}$ & - \\
\hline
\end{tabular}




\section{Discussion}

Sunflower genotypes of diversified origin were evaluated against increased phosphorus level (NP @ 100-90 kg ha ${ }^{-1}$ ) and agronomic as well as seed/leaf P-uptake was compared with recommended dose of fertilizers (NP @ 100-50 kg ha-1) which was considered as control. The results are discussed as under:

The findings of the study showed that values for all the agronomic traits as well as seed/leaf P-uptakes were significantly influenced by increasing the $\mathrm{P}$ level over the control $(\mathrm{P}<0.05)$.

The sunflower crop in treatment and control plots produced plant height $184.39 \mathrm{~cm}$, stem girth $6.45 \mathrm{~cm}$, head diameter 18.85 , head weight $1959.8 \mathrm{~g}$, seeds head ${ }^{-1} 2048.8$ and 1588.5 , shoot dry weight 30.13 and $19.11 \mathrm{~g}$, and $177.69 \mathrm{~cm}$, and $15.72 \mathrm{~cm}$, and $1786.7 \mathrm{~g}$, and $6.22 \mathrm{~cm}$, seed yield $\mathrm{kg} \mathrm{ha}^{-1} 1745$ and $1887.9 \mathrm{~kg} \mathrm{ha}^{-1}$, seed P-uptake 0.252 and $0.109 \%$, leaf P-uptake 0.259 and $0.113 \%$, respectively. Hence, due to increase in $\mathrm{P}$ up to $90 \mathrm{~kg} \mathrm{ha}^{-1}$ over $50 \mathrm{~kg} \mathrm{ha}^{-1}$ seeds head ${ }^{-1}$ increased by $28.98 \%$, shoot dry weight $57.67 \%$, plant height $3.77 \%$, head diameter $19.85 \%$, head weight $9.69 \%$, stem girth $3.70 \%$, seed yield $\mathrm{kg} \mathrm{ha}^{-1} 15.55 \%$, seed Puptake $131.19 \%$ and leaf P-uptake increased by $129.20 \%$ over control. These results agree with those of Ali et al. [22] who found that increased $\mathrm{P}$ application showed a considerable increase in seed yield when compared with control; while other study has indicated that [23] by applying $120 \mathrm{~kg}$ $\mathrm{P}_{2} \mathrm{O}_{5} \mathrm{ha}^{-1}$ has increased yield of $1249.2 \mathrm{~kg}$ $\mathrm{ha}^{-1}$ of sunflower seed as compared to 384.3 $\mathrm{kg} \mathrm{ha}{ }^{-1}$ seed yield in control. In another investigation, Maragatham and Chellamuthu [24] observed that higher $P$ levels positively responded and at $60 \mathrm{~kg} \mathrm{ha}^{-1} \mathrm{P}$ produced the highest seed yield of the sunflower rates. Similarly, Pierzynski et al. [25] argued that the soil has become deficient of $\mathrm{P}$ and needs additional $\mathrm{P}$ supply for achieving desired crop production. Poonia [26] found that 40 $\mathrm{kg} \mathrm{ha} \mathrm{h}^{-1} \mathrm{P}$ gave an economic seed yield of $2373 \mathrm{~kg} \mathrm{ha}^{-1}$ in sunflower. In many another studies in various parts of the world the other researchers [ 27, 28] evaluated and suggested that $40-80 \mathrm{~kg} \mathrm{P} \mathrm{ha}^{-1}$ can be used for achieving economically higher values for head diameter $(13.71 \mathrm{~cm}), 100$-seed weight (5.88 g) and seed yield (998 $\left.\mathrm{kg} \mathrm{ha}^{-1}\right)$ and crop yields in sunflower. In most of the findings, similar results were obtained by many researchers while [29] recommended $120 \mathrm{~kg} \mathrm{P}_{2} \mathrm{O}_{5}$ for achieving desired sunflower yields as compared to recommended $75 \mathrm{~kg}$ $\mathrm{ha}^{-1} \mathrm{P}_{2} \mathrm{O}_{5}$. In other study, [30] argued that phosphorus up to $40 \mathrm{~kg} \mathrm{ha}^{-1}$ was not adequate while $80 \mathrm{~kg} \mathrm{P}_{2} \mathrm{O}_{5} \mathrm{ha}^{-1}$ resulted in higher crop performance in sunflower. [29] Thavaprakash et al. achieved highest sunflower seed yield (3554 kg) with $120 \mathrm{~kg}$ $\mathrm{P}_{2} \mathrm{O}_{5} \mathrm{ha}^{-1}$ over control. Bono et al. [31] obtained greatest sunflower yield $(3750 \mathrm{~kg}$ $\mathrm{ha}^{-1}$ ) with $100 \mathrm{~kg} \mathrm{ha}^{-1}$ phosphorus applied in addition to recommended rates of $\mathrm{N}$ fertilizers. Our results are accordance with the results of [32], who reported that when phosphorus level increases the sunflower yield also increases. Sidiqi et al. [33] observed similar results. They evaluated that higher phosphorus at the rates of 0 , $30,45,60 \mathrm{~kg} \mathrm{ha}^{-1}$ has increased plant height, stem girth, head diameter, seeds head $^{-1}$, seed weight head ${ }^{-1}$, seed index, and seed yield. In another study, Sadozai et al. [34] reported significant effect of $\mathrm{P}_{2} \mathrm{O}_{5} 50$ $\mathrm{kg} \mathrm{ha}^{-1}$ and $60 \mathrm{~kg} \mathrm{ha}^{-1}$ as compare to lower doses of phosphorus on sunflower production; while Radwan et al. [35] suggested $74.4 \mathrm{~kg} \mathrm{P}_{2} \mathrm{O}_{5} \mathrm{ha}^{-1}$ for sunflowers, [36] examined various $P$ levels $(0,80,100$ and $120 \mathrm{~kg} \mathrm{ha}^{-1}$ ) and recommended $120 \mathrm{~kg}$ $\mathrm{ha}^{-1}$ for achieving potential crop performance. Khakwani et al. [37] evaluated different NP levels (50:50:0, 100:100:50 and 150:120:100 kg ha ${ }^{-1}$ ) and higher NP levels recommended for achieving desired sunflower performance. [38, 39] have also 
suggested application of increased $\mathrm{P}$ levels in addition to recommended rates of $\mathrm{N}$ and P. A study was conducted by Aslam [13] in which he found that, the highest yield (2572.64 $\mathrm{kg} \mathrm{ha}^{-1}$ ) were recorded at high level of $\mathrm{P}$ on hybrid sunflower Hysun-33.

The study further showed that $\mathrm{HO}-1$ sunflower variety surpassed all the tested sunflower genotypes for agronomic traits with highest values for seeds head ${ }^{-1}$ (2153.5), shoot dry weight (29.82 g), plant height $(199.97 \mathrm{~cm})$, head diameter $(21.10$ $\mathrm{cm})$, head weight $(2279.1 \mathrm{~g})$, stem girth $(7.13 \mathrm{~cm})$ and seed yield $\left(3.69 \mathrm{~kg} \mathrm{plot}^{-1}\right)$. In genotypes, HO-1 surpassed all the rest of the tested genotypes for agronomic performance; and in seed P-uptake. Chinika $(0.337 \%)$ surpassed other genotypes; while Sputnik $(0.335 \%)$ surpassed all the rest of the genotypes for leaf $\mathrm{P}$-uptake and $\mathrm{P}$ use efficiency ratio of different sunflower genotypes with addition of $\mathrm{P} 90 \mathrm{~kg} \mathrm{P}_{2} \mathrm{O}_{5} \mathrm{ha}^{-1}$ significant $(\mathrm{P}<0.05)$ impact treatment on the P-use efficiency ratio of sunflower genotypes over control. Similar results were obtained by $[25,26,30]$ they indicated that sunflower varieties of diversified origin performed variably for agronomic production and physiological plant characteristics. Similarly, [31, 33-36, 39, 40] argued that sunflower genotypes respond variably to environmental and soil conditions and the crop yield varies accordingly.

\section{Conclusion}

It was concluded that due to increase in $\mathrm{P}$ up to $90 \mathrm{P}_{2} \mathrm{O}_{5} \mathrm{~kg} \mathrm{ha}^{-1}$ over $50 \mathrm{P}_{2} \mathrm{O}_{5} \mathrm{~kg} \mathrm{ha}^{-1}$ seeds head ${ }^{-1}$ increased by $28.98 \%$, shoot dry weight $57.67 \%$, plant height $3.77 \%$, head diameter $19.85 \%$, head weight $9.69 \%$, stem girth $3.70 \%$, seed yield $\mathrm{kg} \mathrm{ha}^{-1} 15.55 \%$, seed P-uptake $131.19 \%$ and leaf P-uptake increased by $129.20 \%$ over control. In genotypes, HO-1 performed the best for agronomic performance, Chinika gave the best performance in seed P-uptake and
Sputnik outdid for leaf P-uptake as compared to other genotypes. On the basis of results and conclusion it is recommended that the sunflower genotype HO-1 may be fertilized with the above mentioned dose of Phosphorus and Nitrogen for potential yield.

\section{Authors' contributions}

Conceived and designed the experiments: NA Talpur, F Soomro \& SB Jamro, Performed the experiments: F Soomro, SB Jamro, AA Panhwar, MH Soomro \& NA Memon, Analyzed the data: N Akhtar \& SB Jamro, Wrote the paper: MK Soothar, JK Soothar \& U Ali.

\section{References}

1. Richard JD, Louis JG \& Henry LA (1984). Crop production. $5^{\text {th }}$ Ed. pp 227229.

2. Demir AO, Buyukcangaz GH \& Koksal ZMTES (2006). Deficit irrigation of sunflower (Helianthus annuus L.) in a sub humid climate. Irriga Sci 24(4): 279-289.

3. Skoric D (1992). Achievements and future directions of sunflower breeding. Field Crops Res 30: 231-270.

4. Rathore VS, Gautam RC \& Kaushik SK (2001). Yield, quality and nutrient uptake by sunflower as influenced by weed and nutrient management. J Annals Agric Res 22(3): 443-444.

5. Hussain MK, Rasul E \& Ali SK (2000). Growth analysis of sunflower under drought conditions. Int J Agri Bio 2: 136140.

6. Razi H \& Asad MT (1998). Evaluation of variation of agronomic traits and water stress tolerant in sunflower conditions. Agric and Natural Resources Sci 2: 3143.

7. Nezami H, Khazaei RZ, Rezazadeh B \& Hosseini A (2008). Effect of drought stress and defoliation on sunflower (Helianthus annuus L.) in controlled conditions. Desert 12: 99-104.

8. Aslam M, Khan MA, Awan IU, Khan EA, Khan AA \& Jilani G (2011). Effect of single and combined use of various organic amendments on wheat grown 
over green manured soil growth and yield attributes. Pak J Nutr 10: 640-646.

9. Shaheen A, Naeem MA, Shafiq M \& Jilani G (2011). Restoring the land productivity through soil water conservation and improved fertilizer application in eroded land of Pothwar plateau in Punjab Province. Pak Plant Prod Sci 14: 196-201.

10. Frossard E, Condron LM, Oberson A, Sinaj S \& Fardeau JC (2000). Processes governing phosphorus availability in temperate soils. J Envir Quality 29: 1523.

11. Griffith B (2010). Efficient Fertilizer UsePhosphorus, pp 1-7.

12. Brady NC \& Weil RR (2002). Soil Phosphorus and Potassium. In: The Nature and Properties of Soils (13th Ed.). Upper Saddle River, NJ: Prentice-Hall, Inc.

13. Aslam N (2014). Growth and yield response of sunflower (helianthus annus l.) to different levels of NPK and sulphur. Thesis submitted to Sindh Agriculture University Tandojam.

14. Shenoy VV \& Kalagudi GM (2005). Enhancing plant phosphorus use efficiency for sustainable cropping. Biotech Adv 23: 501-513

15. Vance, CP (2001). Symbiotic nitrogen fixation and phosphorus acquisition: plant nutrition in a world of declining renewable resources. Plant Physiol 127: 390-397.

16. Saleem, SM, MA Hussain \& SU Anjum (1990). Performance of some sunflower hybrids under farmer conditions. J Animal and Plant Sci Pak 8(3-4) : 123-126.

17. Aziz, Rahmatullah T, Maqsood MA, Tahir MA, Ahmad I \& Cheema MA (2006). Phosphorus utilization by six brassica ultivars (Brassica juncea L.) from tri-calcium phosphate, a relative insoluble compound. Pak J Bot 38: 15291538.

18. Kumar S, Singh AK \& Vyas AK (1995). Effect of $\mathrm{N}$ and $\mathrm{P}$ application on their uptake and biomass production by sunflower (Helianthus annuus L.). Ann Agric Res 16: 513-514.

19. Turk MA \& Tawaha AM (2002). Impact of seedling rate, seeding date, rate and method of phosphorus application in faba bean (Vicia faba L. minor) in the absence of moisture stress. Biotec Agron Soc Environ 6: 171-178.

20. Lickfett, TB Matthaus, Velasco L \& Mollers C (1999). Seed yield, oil and phytate concentration in the seeds of oilseed rape cultivars as affected by different phosphorus supply. Eur J Agron 11: 293-299.

21. Brar MS, Singh B, Bansal SK \& Srinivasrao C (2011). Role of potassium nutrition in nitrogen use efficiency in cereals. Research Findings of Int. Potash Institute, Pp. 29.

22. Ali CK, Nadeem MA \& Javid MA (1997). Effect of nitrogen levels and $P$ application strategy on sunflower. Fertilizer News 42(3): 43-47.

23. Farid S, Hussain SZ, Farida S \& Khan S (2000). Performance of sunflower intercropped in ratoon sugarcane under NP fertilizers. Sarhad J Agric 16(4): 431434.

24. Maragatham S \& Chellamuthu S (2000). Evaluation of various soil test methods for available nitrogen, phosphorus and sulphur for sunflower in inceptisols. $J$ Soils Crops 10(1): 17-20.

25. Pierzynski GM, Sims JT \& Vance GF (2000). Soil phosphorus and environmental quality. In: Soils and Environmental Quality, 2nd Ed. CRC Press, Boca Raton, Florida 155-207.

26. Poonia KL (2000). Effect of planting geometry, nitrogen and sulfur on growth and yield of sunflower (Helianthus annuus L.). J Eco-Physio 3(1/2):59-71.

27. Prasad UK, Yadva VK, Prasad TN, Kumar A \& Prasad SM (2001). Effect of irrigation and nitrogen on oil percentage, yield and water-use efficiency of winter sunflower (Helianthus annuus). Indian $J$ Agron 46(1) : 171-176. 
28. Khanday BA, Singh DK \& Singh JK (2002). Effect of different sowing dates, phosphorus and sulphur levels on the productivity of sunflower under rainfed conditions of Kashmir Valley. Annals Agric Res 23(3): 448-450.

29. Thavaprakash N, Senthilkumar G, Sivakumar SD \& Raju M (2003). Photosynthetic attributes and seed yield of sunflower (Helianthus annuus L.) as influenced by different levels and ratios of nitrogen and phosphorus fertilizers. Acta Agronomica Hungarica 51(2):149155.

30. Maity SK \& Gajendra G (2003). Total productivity, sustainability and recovery of $\mathrm{P}$ and $\mathrm{S}$ by groundnut-sunflower intercropping with simultaneous and staggered planting in relation to $\mathrm{P}$ and $\mathrm{S}$ fertilization. Annals of Agric Res 24 (2): 301-307.

31. Bono A (2006). Doses and application times of nitrogen for sunflower in the semiarid region of La Pampa. Publicación Técnica - INTA. (61): 41-42.

32. Jahangir, AA, Mondal RK, Katrun RS, Afroze N \& Hakim MA (2006). Response of nitrogen and phosphorus fertilizer and plant spacing on growth and yield contributing character of sunflower. Bangl. J Sci Indus Res 41(1/2):33-40.

33. Siddiqui, MH, FC Oad, MK Abbasi \& AW Gandahi (2009). Effect of NPK, micronutrients and $\mathrm{N}$-placement on the growth and yield of sunflower. Sarhad $J$ Agric 25(1): 45-52.

34. Sadozai G, Farhad Khan M, Khan MA, Niamatullah EA, Baloch M, Khakwani
AA \& Wasim K (2013). Effect of Different Phosphorous Levels on Growth, Yield and Quality of Spring Planted Sunflower. Pak J Nutri 12(12): 10701074.

35. Radwan FI, Gomaa MA, Kandil EE \& Homany MM (2013). Effect of plant density and biofertilization on sunflower (Helianthus annuus L.) cv. Sakha 53 productivity. J Agri Bio Sci 9(6): 287295.

36. Garofalo, Chaves LH, Araujo DL, Guerra HOC \& Pereira WE (2104). Response of varying levels of $\mathrm{N}$ fertilizer on yield and oil content of sunflower (Helianthus annuus L.). Amm Soc Agri Biol 23 (7): 123-130.

37. Khakwani AA, Noor S, Sadiq M, Awan IU, Munir M, Baloch MS, Ghazanfarullah \& Bakhsh I (2014). Impact of plant densities and NPK fertilization on growth and optimum economic return of sunflower. Sarhad J Agri 30(2): 157-164.

38. Hassan FU \& Kaleem S (2014). Influence of seasonal disparity on npk uptake in sunflower. J Anim Plant Sci 24(1): 190196.

39. Buriro MR, Solangi M, Soomro AW, Gandahi A, Kashani AW \& Shahabudin (2015). Impact of organic and inorganic manures on sunflower yield and yield components. Int Sci J 27(4): 3267-3270.

40. Olowe VI, Adebimpe OA \& Obadiahi TE (2005). Response of sunflower (Helianthus annuus L.) to nitrogen and phosphorus application in the forestsavanna transition zone of south west, Nigeria. Nigerian J Horti Sci 10: 23-29. 